Revue de droit comparé du travail et de la sécurité sociale

4 | 2017

English Electronic Edition

\title{
Economic Dismissals in the United Kingdom: The Judiciary and its Search for Compliance with EU Law
}

Pascale Lorber

\section{(2) OpenEdition}

Journals

Electronic version

URL: https://journals.openedition.org/rdctss/2328

DOI: $10.4000 /$ rdctss.2328

ISSN: 2262-9815

Publisher

Centre de droit comparé du travail et de la sécurité sociale

\section{Printed version}

Date of publication: 1 December 2017

Number of pages: 182-189

ISSN: $2117-4350$

\section{Electronic reference}

Pascale Lorber, "Economic Dismissals in the United Kingdom: The Judiciary and its Search for Compliance with EU Law", Revue de droit comparé du travail et de la sécurité sociale [Online], 4 | 2017, Online since 01 November 2021, connection on 04 December 2021. URL: http:// journals.openedition.org/rdctss/2328 ; DOI: https://doi.org/10.4000/rdctss.2328

\section{(C) $\Theta \Theta \Theta$}

Revue de droit comparé du travail et de la sécurité sociale est mise à disposition selon les termes de la Licence Creative Commons Attribution - Pas d'Utilisation Commerciale - Pas de Modification 4.0 International. 


\section{ECONOMIC DISMISSALS \\ IN THE UNITED KINGDOM: THE JUDICIARY AND ITS SEARCH FOR COMPLIANCE WITH EU LAW}
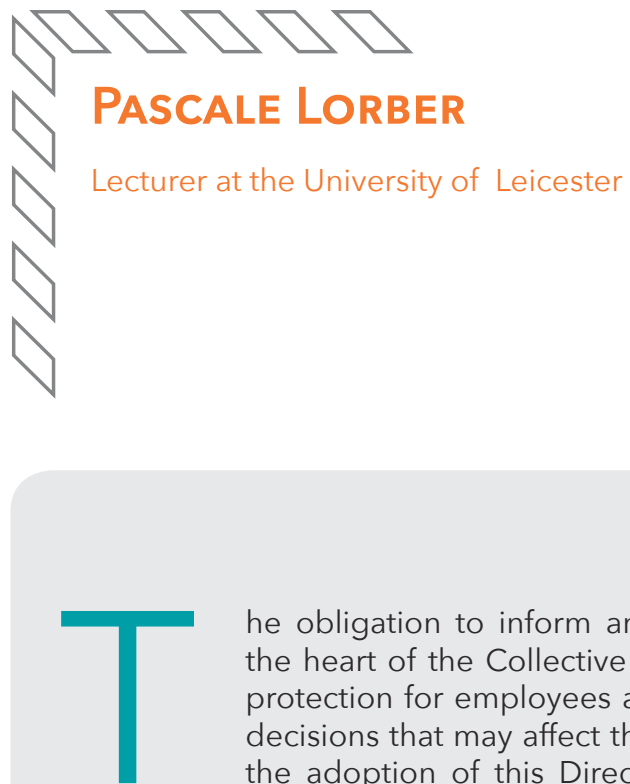

he obligation to inform and consult employee representatives is at the heart of the Collective Redundancies Directive ${ }^{1}$. It is a significant protection for employees as they are given the right to participate in decisions that may affect their livelihood via a collective voice. Before the adoption of this Directive, the UK legislature had not imposed any such obligation to dialogue with the workforce prior to economic dismissals. Judges had therefore to interpret the transposing instrument ${ }^{2}$ in a national vacuum as there was no statutory precedent of involving the workforce in economic or social managerial decisions ${ }^{3}$. Further, they had to ensure that such interpretation was compliant with EU law.

The key provisions dealing with the duty to engage and consult provide that 'Where an employer is proposing to dismiss as redundant 20 or more employees at one establishment within a period of 90 days or less, the employer shall consult

1 Council Directive 98/59/EC of 20 July 1998 on the approximation of the laws of the Member States relating to collective redundancies [1998] OL L225/16.

2 Originally included in the Employment Protection Act 1975. The relevant provisions are now contained in the Trade Union and Labour Relations (Consolidation) Act 1992 (TULRCA), sections 188-192.

3 It should be noted that in addition to the collective obligation to inform and consult triggered when 20 or more employees are at risk of dismissals, there is a parallel procedure that an employer must follow for any economic dismissal, regardless of number involved. If an employee faces termination of employment for redundancy, to avoid a finding of unfair dismissal, case law requires the employer to follow a fair procedure; it involves applying fair and objective selection criteria; warning and consulting the individual employee and seeking suitable alternative employment. The judicial authority for this process is found in Williams v Compair Maxam Ltd [1982] IRLR 83 (EAT) and Polkey v A.E Dayton Services Ltd [1987] IRLR 503 (HL). 
about the dismissals'. ${ }^{4}$ The statute also includes a timetable for consultation (45 days for redundancies over 100 employees and 30 days for less than 100)5; it lists the topics to be considered forinformation and consultation ${ }^{6}$ in linewith the Collective Redundancies Directive and specifies who is to be informed and consulted ${ }^{7}$. Finally, the legislation foresees financial rewards for the affected individuals if the employer fails to inform and consult adequately ${ }^{8}$.

This paper seeks to show that case law has struggled with a number of 'euro' concepts which sit uncomfortably with a legal culture that does not easily challenge the right to manage. Many topics could have been considered but the focus will be on recent case law that deals with the nature of the duty to engage. First, the trigger of the consultation obligation will be assessed. Second, the content of the duty will further demonstrate the discomfort of the judges with some of the European requirements. Final observations will show that the UK judge has endeavoured to comply with EU law despite controversial governmental transposition of EU law and lack of guidance from the Court of Justice of the European Union (CJEU). The conclusion will further seek to consider the implications of Brexit for the judge and national legislation emanating solely from the EU Directive.

\section{I - TRIGGERING THE CONSULTATION PROCESS}

Three elements trigger the obligation to consult as per section 188(1) cited above: first, a numerical threshold of 20 employees; second a temporal requirement of when the manager 'proposes' to dismiss and finally a geographical or physical criteria symbolised by the 'establishment'. Case law has been particularly abundant for the last two components.

\section{A - PROPOSING REDUNDANCIES}

The courts were first exposed to the question of when the process of consultation should start when they were asked whether the term 'proposes' found in the UK statute was compatible with the language of 'contemplates' found in the European Directive'. In $R v$

4 TULRCA 1992, s 188 (1).

5 TULRCA 1992, s 188 (1A). Until April 2013, the consultation period was 90 days for dismissals of more than 100 employees. The Coalition government (2010-2015) had considered that this long period did not enable employers to respond swiftly enough to changes and to restructure effectively (DBIS, Collective Redundancies: Government Response to consultation on changes to the rules (December 2012, URN 12/1352) https://www.gov.uk/government/uploads/system/ uploads/attachment data/file/36737/12-1352-collective-redundancies-government-response-toconsultation.pdf accessed 4 April 2017.

6 TULRCA 1992, s 188 (2).

7 TULRCA 1992, s 188 (1B): this was the subject of controversy with the Commission as the UK had originally only allowed recognised trade unions as possible interlocutors in line with national traditions for collective issues. This was however considered as a faulty implementation of the Directive by the European Court as employees in workplaces where unions were not recognised were deprived of the right to information and information (recognition by an employer was discretionary at the time). The UK subsequently amended its statutes by providing alternative methods to appoint employee representatives where unions were not recognised. EU law therefore created dual channel representation in the UK. See Case C-383/92 Commission v UK [1994] ECR I-2479 (ECJ) and P Davies, 'A challenge to single channel' (1994) 23 Industrial Law Journal 272.

8 TULRCA 1992, s 189.

9 Art 2. 
British Coal Corporation ex parte Vardy ${ }^{10}$, it was clearly established that the two words were not synonymous and that the UK triggering point was much later in the decision-making process than the Directive had envisaged:

'proposes' relates to a state of mind which is much more certain and further along the decision-making process than 'contemplates'; in other words, the Directive envisages consultation at an early stage when the employer is first envisaging the possibility that he may have to make employees redundant. Section 188 applies when he has decided that, whether because he has to close a plant or for some other reason, it is his intention, however reluctant, to make employees redundant. ${ }^{11}$

Given the choice of word by the legislator, courts could not see how they could interpret 'proposes' as meaning 'contemplates' and considered the process as starting when a decision had been made that there would be redundancies: 'Section 188(1) cannot be construed to accord with Article 2(1) of the EC Collective Redundancies Directive without distorting the meaning of the domestic legislation.' ${ }^{12}$ This interpretation reduced the consultation exercise to conversations about the implementation of the redundancies rather than questioning whether there should be redundancies at all.

The view was called into question by the European case of Junk $v$ Kuhne/13 which interpreted the word 'contemplates' and stated

The case in which the employer 'is contemplating' collective redundancies and has drawn up a 'project' to that end corresponds to a situation in which no decision has yet been taken $[\ldots]$.

Thus, the terms used by the Community legislature indicate that the obligations to consult and to notify arise prior to any decision by the employer to terminate contracts of employment. $^{14}$

National case law adapted and interpreted TULRCA 1992 according to the EU construction, indicating that 'a proposal must be less than a decision that dismissals are to be made and more than a possibility that they might occur' ${ }^{\prime 15}$. The court's attitude demonstrated a willingness to assign a closer meaning to the European concept and its implications: the necessity to consult before a final decision was made.

The water was however muddied by the European case of Akavan v Futjitsu ${ }^{16}$ which defined 'contemplates' in a narrower and more complex fashion: 'the consultation procedure must be started by the employer once a strategic or commercial decision compelling him to contemplate or to plan for collective redundancies has been taken'17. The complex definition tried to find a balance between triggering the obligation too early, increasing anxiety for employees about their employment and too late to deprive workers' representatives of a true opportunity to discuss management's decision to avoid redundancies. The language used however did not helped courts understanding when to pinpoint the timing of the duty.

10 [1993] IRLR 104 (HCQB).

11 Ibid [124]v

12 MSFv Refuge Assurance Plc and another [2002] IRLR 324 (EAT).

13 Case C-188/03, Junk v Kuhnel [2005] IRLR 310 (CJEU).

$14 \mathrm{Ibid}[35]$ and [36].

15 Leicestershire County Council v Unison [2005] IRLR 920 (EAT) [32].

16 Case C-44/08 Akavan Erityisalojen Keskusliitto Aekktry and others v Fujitsu Siemens Computers Oy [2009] IRLR 944 (ECJ).

17 Ibid [48]. 
As a result of the mixed messages found in Junk and Akavan, the UK Court of Appeal sought further clarification on the meaning of contemplates from the CJEU. In the case of USA $v$ Nolan, the United States government decided to close a military base in the United Kingdom. This led to the dismissal of about 200 civilians. One of the questions before the court was whether consultation should have occurred earlier than when the decision had been made to dismiss all employees. The Court of Appeal asked the Court of Justice the following questions: does the duty to consult arise (i) when the employer is proposing, but has not yet made, a strategic business or operational decision that will foreseeably or inevitably lead to collective redundancies; or (ii) only when that decision has actually been made and he is then proposing consequential redundancies? ${ }^{18}$

Unfortunately, the European Court refused to rule on the basis that it had no jurisdiction ${ }^{19}$ because the European Directive did not apply to public administration and military services fell in that category ${ }^{20}$. This was despite the fact that such exclusion was not transposed in UK law. The question therefore returned to national courts with the Supreme Court eventually indicated that 'So the questions raised by [...] the Court of Appeal's reference will in the present case have to be resolved, if ever necessary, domestically without further assistance from the Court of Justice'21. However, the legal arguments were a complex set of issues on state immunity and whether national or EU law should apply where a foreign government makes a decision to close a military base in a Member States. The Supreme Court indicated that section 188 would apply and remitted the case to the Court of Appeal, the task to deal with this issue. At the time of writing, no decision is yet available.

The attempt by the courts to read national legislation according to the latest guidance which remains Akavan is evident in the most recent case of E Ivor Hughes Educational Foundation $v$ Morris ${ }^{22}$. The question was whether a proposal to close a school triggered consultation at the time where school governors met and proposed to close the school if the number of students did not increase or a few weeks later when they eventually agreed to close the school. The Employment Appeal Tribunal (EAT) agreed with the Employment Tribuna ${ }^{23}$ which had assessed that the proposal occurred in the first meeting, applying the trigger before the decision was final.

While the commencement of the duty continues to challenge national and European judges, so does the concept of establishment.

18 Case C-583/10 [2011] OJ C 89/4.

19 Case C-583/10 USA v Nolan [2013] ICR 193 (CJEU).

20 Art 1(2).

21 United States of America v Nolan [2015] UKSC 63 [10].

22 [2015] IRLR 696 (EAT).

23 Employment disputes are heard by Employment Tribunals in first instances (with some exceptions found in the legislation); an appeal on a point of law reaches the Employment Appeal Tribunal. A further hearing can reach the Court of Appeal and subsequently the Supreme Court. 


\section{B - ESTABLISHMENT}

The CJEU had established early that the unit of establishment, as defined by national law, could not be used to defeat the protective aim of the Directive ${ }^{24}$. Establishment was thus given a European definition of:

designating, depending on the circumstances, the unit to which the workers made redundant are assigned to carry out their duties. It is not essential in order for there to be an 'establishment' for the unit in question to be endowed with a management which can independently effect collective redundancies ${ }^{25}$.

The subsequent case law from the CJEU also attempted to 'maximise the application of the duty to consult' ${ }^{26}$. The UK courts struggled to assign a relevant definition to the concept which was not explained in statute. Establishing what an establishment was a question of facts, leading to cases with opposite outcomes. Giving a too narrow definition (ie an establishment is a small unit) may assist employers in avoiding the obligation with the 20 threshold rarely being met. On the other hand, using too wide a definition, considering the establishment as the employer, could lead to most economic dismissal being caught by section 188 TULRCA 1992. For example in an earlier case of Barrat Developments (Bradford) Ltd $\vee$ UCATT ${ }^{27}$, the judge found that fourteen separate sites could be considered as one establishment instead of fourteen separate ones. Conversely, in Renfrewshire Council $v$ Educational Institute of Scotland ${ }^{28}$, the EAT found that teachers are assigned to a school, as the establishment, rather than the local authority which manages the school and has some powers of the employer. The judge indicated that the test is employee focussed: was the person assigned to a unit that can be classified as an establishment? Establishment is less than an undertaking and connotes a physical environment, not an organisational one ${ }^{29}$.

A UK court eventually sought clarification from the European judiciary when the firms Woolworths and Ethel Austin, large retailing companies, went into liquidation, closing down all their shops in the UK. The question was whether, in a multi site setting, there was an obligation to consult in places where less than 20 employees were present. This had been raised following the refusal of the company to pay compensation for lack of consultation to employees who worked in shops or units where less than 20 people were employed. Section 188 TULRCA refers to the obligation to consult where there are dismissals at 'one establishment'. The Employment Appeal Tribunal took a bold purposive approach stating that '...the words 'at one establishment' should be deleted from s.188 as a matter of construction... ${ }^{30}$ in order to give proper effect to the Directive's purpose. The consequence was the reading of establishment as the whole company in such a scenario. This finding was appealed to the Court of Appeal, which given the need to comply with the EU definition, referred the case to the CJEU ${ }^{31}$. The latter took a different view and counterbalanced the social protection aim of the Directive with the need to 'ensure

C- 449/93 Rockfon A/S v Nielsen [1996] IRLR 168, 175.

Ibid [32].

S Deakin and G S Morris, Labour Law (6 $6^{\text {th }}$ ed, Hart Publishing 2012) 923.

[1977] IRLR 403 (EAT).

[2013] IRLR 76 (EAT).

Ibid.

30 USDAW v Ethel Austin Ltd (Administration) [2013] IRLR 686 (EAT) [53].

31 USDAW and another $v$ Austin Ltd (in administration) and another [2014] EWCA Civ 172. 
comparable protection for workers' rights in the different Member States and to harmonise the costs which such protective rules entail for EU undertakings' ${ }^{32}$. The Court also reiterated that an establishment is a different unit than an undertaking ${ }^{33}$. As a result, it considered that the definition of establishment 'requires that account be taken of the dismissals effected in each establishment considered separately' ${ }^{\prime 34}$.

The outcome is the arbitrary exclusion of some employees from the right of information and consultation depending on where they are employed (a larger or smaller unit of the business). This interpretation seemed contrary to previous EU case law and to what the national court had found as it had taken a more purposive approach than the European court. The unfortunate effect was the depriving of compensation for lack of consultation to all employees employed in smaller units.

\section{II - THE CONTENT OF THE OBLIGATION}

The duty to engage in UK law has been primarily copied from article 2 of the Directive with one exception allowing the employer to justify lack of consultation. The national judge still had to consider interpreting the content of the obligation, in particular, the scope of the concept of avoiding redundancies and 'seeking to reach an agreement'.

\section{A - TOPICS OF INFORMATION AND CONSULTATION}

When dismissals are proposed, the employer must inform and disclose in writing to the workers' representatives a number of specified matters listed in TULRCA 1992, section 188(4) including the reasons for his proposal; the numbers and description of employees it proposes to dismiss; the total number of employees employed in the establishment; the proposed method of selecting the employees dismissed; the proposed method of carrying out the dismissal; the proposed method of calculating redundancy pay. The consultation process is described in TULRCA 1992, section 188(2) and requires the employer to consult on ways of avoiding the dismissal, reducing the number of employees to be dismissed and mitigating the consequences of dismissals.

The question that arose in courts was whether the employer must consult on the reasons for the redundancies. While information must be provided on the reasons for the proposal, the statute or the directive do not require consultation on such reasons. This is undoubtedly seen as part of the managerial prerogative. However, in the case of UK Coal Mining Ltd $v$ National Union of Mineworkers (Northumberland Area) and another ${ }^{35}$, the employer closed down a colliery, informing the employee representatives that the closure was for health and safety reasons when it was proven that it was for economic reasons. The principal question was whether trade unions should have been consulted about the reasons for the closure. The EAT indicated that consultation should be about avoiding

32 Case C-80/14 USDAW and another $v$ WW Realisation 1 Ltd (in liquidation) and others; the case was joined with an Irish case where very similar facts had arisen: Case C-182/13 Lyttle and others v Bluebird UK Bidco 2 Ltd, [2015] IRLR (CJEU) 577 [62].

33 Ibid [69].

34 Ibid [68].

35 [2008] IRLR 4 (EAT). 
the dismissals and clearly this would involve discussing the reasons for the closure. While, this finding goes beyond what the statute requires, the judge stated:

But the obligation to consult over avoiding the proposed redundancies inevitably involves engaging with the reasons for the dismissals, and that in turn requires consultation over the reasons for the closure. Strictly, of course, it is the proposed dismissals that are the subject of consultation, and not the closure itself. [...] Where closure and dismissals are inextricably interlinked, the duty to consult over the reasons arises ${ }^{36}$.

The case therefore, not only deals with the topics of consultation, but links with the question of timing of the obligation: if the closure is proposed, the decision is made, amounting to a fait accompli and the consultation is restricted to handling the redundancies. It is further intertwined with the nature of the duty as consulting over the reasons for redundancies allows a more significant influence on the possible final outcome. The case of UK Coal Mining was therefore used to substantiate the claim in USA $v$ Nolan that consultation should have taken place before the proposal to close the military base. As the outcome of USA $v$ Nolan is still pending, it could be argued that UK Coal Mining remains good law 37 .

\section{B - OUTCOME: SEEKING AN AGREEMENT}

Finally, the employer must undertake the consultation with a view to 'reaching an agreement' with the appropriate representatives. While the process of consultation is not further defined in the relevant statute, it is understood that it would usually involve representation made by the workers' representatives and a response by the employer to such representation, with a view to finding some consensus ${ }^{38}$. It is also generally considered by academics and trade unions that consultation is not negotiation and the ultimate decision always lies with the employer ${ }^{39}$.

However, in Kelly $v$ Hesley, the EAT reminded the employer that consultation with a view to reaching an agreement was not to be equated merely to the passive receipt of information about an employer's plan - it was more akin to negotiations ${ }^{40}$. Further, it was also stressed that the burden is on the employer to provide written information and to engage in all the aspects of the consultation even if they are not mentioned by the employee representatives.

\section{C - JUSTIFYING THE LACK OF CONSULTATION}

A noticeable exception to the Directive is found in UK law in the form of a defence available to the employer for lack or incomplete consultation. Section 188(7) TULRCA 1992 states that if the employer can prove that special circumstances rendered the process of information and consultation not reasonably practicable, the lack of consultation can be

36 Ibid [87].

37 The uncertainty of the law is highlighted in the Ivor case ( $\mathrm{n} 20$ ) at [51].

38 See for example a guide on Handling Large Scale Redundancies produced by the Advisory, Conciliation and Arbitration Services (ACAS), an independent body that promotes good practice and advise employers and employees (http://www.acas.org.uk/media/pdf/c/p/Handling-largescale-collective-redundancies-advisory-booklet.pdf accessed 4 April 2017).

39 G S Morris and T J Archer, Collective Labour Law (Hart Publishing 2000) 299.

40 [2013] IRLR 514 (EAT). 
justified. As such defence is unavailable under EU law, the judiciary approached it with caution and as a result, it has been construed consistently restrictively. In the very early case of Clark's of Hove $v$ Bakers' Union ${ }^{41}$, it was held that insolvency is not enough special circumstances, principally because it could be foreseen to a certain extent. It is only if sudden disaster strikes a company, making it necessary to close the concern, that special circumstances could be envisaged. The disaster could be physical or financial. This narrow approach was confirmed in the more recent case of E Ivor v Morris ${ }^{42}$, where it was reiterated that the circumstances must be 'out of the ordinary; something uncommon' ${ }^{43}$. The risk that the information that the school may close is leaked to the parents did not constitute such special circumstances.

\section{III - THE IMPACT OF BREXIT}

The case law on when and how to consult in economic dismissals has proven a difficult guessing game for UK national courts. While the statutory language was unhelpful, the last few years have seen an attempt by the courts to adjudicate in the spirit of the Directive. When the national judge sought clarification from the EU court, the latter refused to engage or limited the social protection provided by the Directive. In a context of Brexit, it is unclear how national courts will react in the future. While EU legislation, including labour law measures, will remain on the national statute book thanks to a Great Repeal Act that will copy and paste EU law into national law, it could be subject to future changes by the legislature depending on the political colour of the government in place ${ }^{44}$. By contrast, it is less clear how national courts will interpret provisions which have EU origins once the UK is out of the EU. Questions on whether they will continue to look to Luxembourg to consider European interpretation remain without answers at the time of writing. Given the strong position of the current government to exclude any role of the European Court, it is more likely that UK courts will develop their own views of what the legislation means.

41 [1978] ICR 1076, (CA).

42 [2015] IRLR 696 (EAT).

43 Ibid [32].

44 M Ford, 'The Impact of Brexit on UK Labour Law' (2016) 32(4) International Journal of Comparative Labour Law and Industrial Relations 473. 